\title{
STUDY ON RELATION BETWEEN PLACENTAL LATERALITY IN SECOND TRIMESTER ULTRASOUND AND DEVELOPMENT OF PREECLAMPSIA AT TERM
}

\author{
Preety Aggarwal', Phalguni Kangjam², Nounenuo Terhase ${ }^{3}$ \\ ${ }^{1}$ Senior Resident, Department of Obstetrics and Gynaecology, Maharaja Agrasen Medical College, Agroha, Hisar, Haryana. \\ ${ }^{2}$ Senior Resident, Regional Institute of Medical Sciences, Imphal, Manipur. \\ 3Medical Officer, PHC, Mokokchung, Nagaland.
}

\section{ABSTRACT}

\section{OBJECTIVE}

To find whether placental laterality as determined by ultrasound can be used as predictor for the development of preeclampsia.

\section{METHODS}

This prospective study was conducted on pregnant women attending the antenatal clinic of Regional Institute of Medical Sciences, Imphal, Manipur, from October 2012 till September 2014; 475 pregnant women attending antenatal clinic both OPD and IPD at 18-24 weeks of gestation without any high risk factor were subjected to ultrasound examination and placental location was determined. These cases were followed for the development of signs and symptoms of preeclampsia.

\section{RESULT}

Out of the total 475 women, 263(55.4\%) had laterally located placenta and of them $45(17.1 \%)$ developed preeclampsia, while the remaining $212(44.6 \%)$ had centrally located placenta and of them $13(6.1 \%)$ developed preeclampsia. So, the overall risk of developing preeclampsia with laterally located placenta was 3.16 (odds ratio) and 95\% confidence interval (1.65-6.03). The difference was found to be statistically significant, $\mathrm{p}$ value $(0.0005)$ by $\chi^{2}$ test.

\section{CONCLUSION}

From the above study, we concluded that females with laterally located placenta determined by USG at 18-24 weeks of gestation have greater risk of developing preeclampsia.

\section{KEYWORDS}

Placental laterality, Preeclampsia, Central placenta.

HOW TO CITE THIS ARTICLE: Aggarwal P, Kangjam P, Terhase N. "Study on relation between placental laterality in second trimester ultrasound and development of preeclampsia at term." Journal of Evolution of Medical and Dental Sciences 2015; Vol. 4, Issue 104, December 28; Page: 16926-16928, DOI: 10.14260/jemds/2015/2550

\section{INTRODUCTION}

Hypertensive disorders complicate $5-10 \%$ of all pregnancies. ${ }^{1}$ The presence of a placenta is necessary to cause the disorder. The placental problem appears to be a relative failure of the uteroplacental circulation owing to spiral artery disease with consequent hypoxia, oxidative stress and diminished placental function. The histological abnormalities of placenta in pregnancy are characterised by cytotrophoblast prominence and abnormalities in syncytiotrophoblast formation. Placental location has been found to correlate with fetal position and presentation, length of gestation, course of labour, presence of preeclampsia and perinatal outcome. Several methods have been used to document placental location including manual exploration of uterus, soft tissue x-ray films, ultrasonography, magnetic resonance imaging and isotropic placentography. In the past three decades ultrasonography has proved to be the safest, easiest and most accurate method of assessing placental location. In humans, both uterine arteries have a significant number of branches and that each supply the corresponding side of the uterus.

Financial or Other, Competing Interest: None.

Submission 01-12-2015, Peer Review 05-12-2015,

Acceptance 24-12-2015, Published 26-12-2015.

Corresponding Author:

Dr. Preety Aggarwal,

Senior Resident,

Department of Obstetrics and Gynecology,

Maharaja Agrasen Medical College,

Agroha, Hisar, Haryana.

E-mail: ardentpreety@gmail.com

DOI:10.14260/jemds/2015/2550
Although anastomosis between the two uterine arteries exist, there is no proof that these are functional. When the placenta is laterally located, the uterine artery closer to the placenta has lower resistance than the one opposite to it. In patients with centrally located placenta, both uterine arteries demonstrated similar resistance. ${ }^{2}$ When the placenta is centrally located, the uteroplacental blood flow needs are met by equal contribution from both uterine arteries. However, when the placenta is laterally located, the uteroplacental blood flow needs are met primarily by ipsilateral uterine artery with some contribution from contralateral uterine artery via the collateral circulation. ${ }^{3}$ The degree of collateral circulation may not be the same in all patients and deficient contribution may facilitate the development of preeclampsia, intrauterine growth retardation or both. The significance of normal placentation for this cytotrophoblastic invasion is high and the cytotrophoblasts fail to adopt a vascular adhesion phenotype in preeclampsia. This may explain the reduced trophoblastic invasion in laterally situated placenta when the uteroplacental blood flow needs are mainly met by one side uterine artery.

\section{MATERIALS AND METHODS}

A prospective study was conducted on 475 pregnant women with singleton pregnancies attending the antenatal clinic of Regional Institute of Medical Sciences, Imphal, Manipur, from October 2012 till September 2014.

\section{Inclusion Criteria}

Randomly, pregnant women with singletom pregnancy attending antenatal clinic with period of gestation $\geq 18$ weeks and $\leq 24$ weeks were selected. 


\section{Exclusion Criteria}

Pregnant women having chronic hypertension or essential hypertension, diabetes mellitus, thyrotoxicosis, renal disease, severe anemia, connective tissue disorder, positive lupus anticoagulant anticardiolipin antibodies, RH incompatibility, twin pregnancy or positive VDRL test were excluded.

Ethical approval was taken from Institution Ethical Committee, RIMS, Imphal, Manipur, before starting the study. Informed consent was taken from all clients willing to participate before enrolling them in the study. However, patients were asked to stop participating at any time if they wished. Detailed clinical history including parity, obstetrical history was taken along with General examination, systemic examination and obstetrical examinations. All the routine investigations including complete hemogram, urine examination, liver and kidney function test, $\mathrm{ABO}$ grouping and $\mathrm{Rh}$ typing, blood sugar estimation were carried out.

Location of placenta was determined by ultrasound in 18-24 weeks of pregnancy by using SONOACE X8, Medison and NEMIO XG, Toshiba. The placenta is classified as central when placental mass is equally distributed between the right and left side of the uterus irrespective of anterior, posterior or fundal position. When more than $75 \%$ of placental mass is on one side of the midline, it is classified as unilateral right or unilateral left placenta. The end point of the study was the development of hypertension in pregnancy (As per American criteria of obstetrics and Gynaecology) or delivery.

\section{RESULTS}

Majority of the pregnant women were from the age group 2125 years, i.e. 207(43.6\%). Primipara constituted $41 \%$ of the cases. More than half of the women had lateral placenta (55.4\%). Out of 475 patients, only 58(17.8\%) patients develop hypertension our study showed that among women having lateral placenta $17.1 \%$ of cases developed PIH, but among women with central placenta only $6.1 \%$ of cases developed $\mathrm{PIH}$. These findings were found to be statistically significant $(p<0.05)$. The odds of developing PIH were 3.16 times more among women with lateral placenta than women with central placenta $(p<0.05) ; 54.8 \%$ of mild hypertensive cases had laterally located placenta. In severe hypertensive cases, laterally located placenta was more as compared to centrally located placenta but the findings were found to be insignificant.

\section{DISCUSSION}

Preeclampsia/eclampsia is one of the 3 leading causes of worldwide maternal morbidity and mortality. The search for an ideal predictive test and preventive measure remains challenging. It has been shown that in humans, both uterine arteries have a significant number of branches and that each supply the corresponding side of the uterus. Although anastomoses between the two uterine arteries exist, there is no proof that they are functional. When the placenta is laterally located, the uterine artery closer to the placenta has lower resistance than the one opposite to it. In women with centrally located placenta, both uterine arteries have similar resistance and the uteroplacental blood flow needs are met by equal contribution from both uterine arteries.

However, when the placenta is laterally located, in majority of the cases, the uteroplacental blood flow needs are met primarily by one of the uterine arteries with some contribution from the other uterine artery via the collateral circulation. There are various methods to predict or to diagnose preeclampsia. Out of all, placental localisation in second trimester by ultrasound is very useful, easy and noninvasive method to diagnose preeclampsia. Other easy and noninvasive method to predict is Doppler study of uterine arteries in second trimester.
This cross-sectional study included 475 pregnant women attending antenatal clinic of Obstetrics and Gynaecology, RIMS, Imphal, between October 2012 to September 2014. Second trimester ultrasound was done for all the patients between 18-24 weeks and placental position is determined. Patients are followed till development of preeclampsia or till delivery. In this study majority of the women were from the age group 21-25 years (43.6\%) (Table 1). Primipara constituted most of the women included in my study (41\%) (Table 2). More than half of the women, in this study, had their placenta laterally located (55.4\%) (Table 3). This finding is consistent with study done by Shivamurthy HM et al. ${ }^{4}$ and by Tania K et al. 5 Out of total cases, $17.8 \%$ developed preeclampsia (Table 4). Out of 263 cases of laterally located placenta, 45 cases developed preeclampsia (17.1\%) (Table 5), which was more than that developed among centrally located placenta cases (6.1\%) (Table 5) and this finding was statistically significant $(\mathrm{p}<0.05)$.

So development of preeclampsia is associated more with the laterally located placenta. This result is consistent with the studies by Tania K et al. ${ }^{5}$ Anuja VB et al. ${ }^{6}$ and Pai MV et al. ${ }^{7}$ Odds ratio in this study was 3.16 i.e., there is 3.16 times higher chances of development of preeclampsia among laterally located placenta than centrally located placenta. This finding is consistent with study by Anuja VB et al. ${ }^{6}$ Kofinas AD et al. ${ }^{8}$ and Gonser $\mathrm{M}$ et al. ${ }^{9}$ This is also comparable with the study by Tania K et al. ${ }^{5}$ and Seadati N et al. ${ }^{10}$ where the odds ratios were 5.09 and 5.6 respectively. In the present study, hypertension was mild in most of the cases (84.5\%) (Table 6) and both mild and severe form of hypertension are more common with laterally located placenta. But, the difference between the severity of hypertension and location of placenta is not statistically significant.

\section{CONCLUSION}

From the above study, it is concluded that laterally located placenta on ultrasound done at 18-24 weeks is associated with increased risk of development of preeclampsia. Females with laterally located placenta have a greater risk of developing $\mathrm{PIH}$, so these pregnancies may require careful obstetric management to achieve a more favorable outcome and decrease the maternal and perinatal morbidity and mortality associated with preeclampsia.

\section{Disclosure of Interests}

None of the authors has any financial, personal, political, academic or other relationships that could lead to a conflict of interest relevant to this article.

\section{Contribution to Authorship}

PA and TND were involved in concept and design of the study. PA performed the experiments and analysis of the data was done by PA in corroboration with KN and TND. PA and KN contributed for reagents/ materials and analysis tool. PA wrote the initial article. All authors critically reviewed the subsequent versions of the article and approved the final version.

\section{Details of Ethics Approval}

Ethical approval was taken from Institution Ethical Committee, RIMS, Imphal, Manipur in September 2012 and also the consent from all participants.

\section{REFERENCES}

1. Report of the National High Blood Pressure Education Program Working Group on High Blood Pressure in Pregnancy. Am J Obstet Gynecol 2000;183(1):1-22.

2. Campbell S, Bewbey S, Cohen-Overbeek T. Investigation of uteroplacental circulation by Doppler ultrasound. Semin perinatol 1987;11:362. 
3. Fleischer A, Schulman H, Farmakides G, Bracero L, Grunfeld L, Rochelson B. Uterine artery Doppler velocimetry in pregnant women with hypertension. Am J Obstet Gynecol 1986;154:806-13.

4. Shivamurthy HM, Sharada KS, Giridhar SA, et al. Placental laterality as a predictor of pre-eclampsia-An ultrasonic prospective study. J Pub Health Med Res 2014;2(1):3840.

5. Tania K, Virender S, Manisha K. Placental Laterality as a Predictor for Development of Preeclampsia. J Obstet Gynecol India 2013;63(1):22-5.

6. Anuja VB, Sayali K, Savita S. Lateral Placentation by Ultrasonography: A Simple Predictor of Preeclampsia. J South Asian Feder Obst Gynae 2013;5(2):68-71.

7. Pai MV, Pillai J. Placental laterality by ultrasound - a simple yet reliable predictive test for preeclampsia. J Obstet Gynecol India 2005;55(5):431-3.

8. Kofinas AD, Penry M, Swain M. Effect of placental laterality on uterine artery resistance and development of preeclampsia and intrautrine growth retardation. Am J Obstet Gynecol 1989;161:153-69.

9. Gonser M, Tillack N, Pfeiffer KH, et al. Placental location and incidence of preeclampsia. Ultraschall Med 1996;17:236-8.

10. Seadati N, Najafian $M$, Cheraghi $M$, et al. Placental Location at Second Trimester and Pregnancy outcomes. J Pharm Sci Innov 2013;2(2):32-4.

\begin{tabular}{|c|c|c|}
\hline AGE IN YEARS & NUMBER & PERCENTAGE \\
\hline$\leq 20$ & 36 & 7.6 \\
\hline $21-25$ & 207 & 43.6 \\
\hline $26-30$ & 150 & 31.6 \\
\hline$>30$ & 82 & 17.2 \\
\hline TOTAL & 475 & 100.0 \\
\hline \multicolumn{3}{|c|}{ Table 1: Distribution of respondents based on age } \\
\hline
\end{tabular}

\begin{tabular}{|c|c|c|}
\hline PARITY & NUMBER & PERCENTAGE \\
\hline Nullipara & 121 & 25.5 \\
\hline Primipara & 195 & 41.0 \\
\hline Multipara & 159 & 33.5 \\
\hline TOTAL & $\mathbf{4 7 5}$ & $\mathbf{1 0 0 . 0}$ \\
\hline \multicolumn{2}{|c|}{ Table 2: Distribution of respondents by parity } \\
\hline
\end{tabular}

\begin{tabular}{|c|c|c|}
\hline $\begin{array}{c}\text { PLACENTAL } \\
\text { LOCATION }\end{array}$ & NUMBER & $\begin{array}{c}\text { PERCENTAG } \\
\text { E }\end{array}$ \\
\hline Lateral & 263 & 55.4 \\
\hline Central & 212 & 44.6 \\
\hline TOTAL & $\mathbf{4 7 5}$ & $\mathbf{1 0 0 . 0}$ \\
\hline $\begin{array}{c}\text { Table 3: Distribution of respondents by } \\
\text { placental location by ultrasound }\end{array}$ \\
\hline
\end{tabular}

\begin{tabular}{|c|c|c|}
\hline PREECLAMPSIA & NUMBER & PERCENTAGE \\
\hline Yes & 58 & 17.8 \\
\hline No & 417 & 82.2 \\
\hline TOTAL & $\mathbf{4 7 5}$ & $\mathbf{1 0 0 . 0}$ \\
\hline $\begin{array}{r}\text { Table 4: Distribution of respondents by } \\
\text { development of Preeclampsia }\end{array}$ \\
\hline
\end{tabular}

\begin{tabular}{|c|c|c|c|c|c|}
\hline $\begin{array}{l}\text { PLACENTAL } \\
\text { LOCATION }\end{array}$ & \multicolumn{2}{|c|}{$\begin{array}{c}\text { OUTCOME } \\
\text { PREECLAMPSIA } \\
\text { YES NO } \\
\end{array}$} & TOTAL & $\begin{array}{c}\text { ODDS } \\
\text { RATIO }\end{array}$ & $\begin{array}{c}\text { CHI } \\
\text { SQUARE TEST }\end{array}$ \\
\hline LATERAL & $45(17.1 \%)$ & $218(82.9 \%)$ & $\begin{array}{c}263 \\
(100.0)\end{array}$ & \multirow{3}{*}{$\begin{array}{c}3.16 \\
(1.65-6.03) \\
p-0.0005\end{array}$} & \multirow{3}{*}{$\begin{array}{c}13.1972 \\
\mathrm{p}-0.00028\end{array}$} \\
\hline CENTRAL & $13(6.1 \%)$ & 199(93.9\%) & $\begin{array}{c}212 \\
(100.0)\end{array}$ & & \\
\hline TOTAL & $\begin{array}{c}58 \\
(17.8)\end{array}$ & $\begin{array}{c}417 \\
(82.2)\end{array}$ & $\begin{array}{c}475 \\
(100.0)\end{array}$ & & \\
\hline
\end{tabular}

\begin{tabular}{|c|c|c|c|c|}
\hline $\begin{array}{c}\text { SEVERITY OF } \\
\text { HYPERTENSION }\end{array}$ & \multicolumn{2}{|c|}{$\begin{array}{l}\text { PLACENTAL LOCATION } \\
\text { Central Lateral }\end{array}$} & TOTAL & $\begin{array}{c}\text { FISHER } \\
\text { EXACT TEST }\end{array}$ \\
\hline Mild & $12(24.5 \%)$ & $37(75.5 \%)$ & $49(84.5 \%)$ & \\
\hline Severe & $1(11.1 \%)$ & $8(88.9 \%)$ & $9(15.5 \%)$ & 0.78 \\
\hline TOTAL & $13(22.4 \%)$ & $45(77.6 \%)$ & $58(100.0)$ & p-0.66 \\
\hline
\end{tabular}

